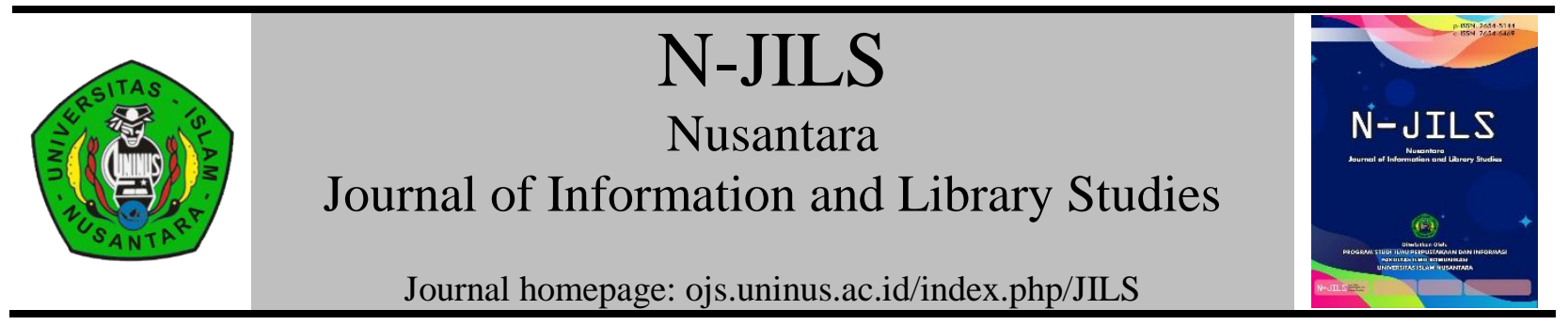

\title{
Pemanfaatan Media Sosial sebagai Sarana Promosi Layanan Perpustakaan Institut Seni Indonesia Surakarta
}

\section{Utilization of Social Media as a Means of Promoting Library Services in Indonesia Institute of the Arts Surakarta}

\author{
M. Ali Nurhasan Islamy ${ }^{1}$, Ika Laksmiwati ${ }^{2}$ \\ ${ }^{1,2}$ Institut Seni Indonesia (ISI) Surakarta \\ e-mail: ali_enhai@yahoo.com, ${ }^{2}$ laksmiwatii@gmail.com
}

\begin{tabular}{ll}
\hline ARTICLE INFO & ABSTRACT \\
\hline Article history & This study is entitled Utilization of Social Media as a \\
Received [May 2020] & Means of Promoting Library Services in Indonesia Institute \\
Revised [June 2020] & of the Arts Surakarta. The purpose of this research is to find \\
Accepted [June 2020] & out whether social media (Facebook) can provide \\
Available Online [June 2020] & convenience in introducing various services, providingan \\
an information to users in the current style. In addition, to & find out whether facebook can be used to effectively \\
promoting an information services and activities in the & library. Researchers will look at facebook, collect \\
& documentation data on facebook library pages and analyze \\
them using descriptive qualitative analysis. The approach \\
used is a qualitative approach, namely research that \\
describes the phenomenon, digging data by interviewing \\
informants, observation and documentation. Researchers' \\
technique in finding data will be done directly through \\
online media or the internet by structured interviews and \\
checklists. It's just that if needed the researcher will meet \\
directly the informant. Researchers assume that social \\
media can be used as a substitute for the promotion of \\
library services in the form of online or softcopy and \\
simultaneously to many people and quickly and sometimes
\end{tabular}


even immediately get a response or public response. In addition, promotion with social media can attract users to take of library facilities and participate in library activities and as a media for documentation of various activities in the library. The results of this research are expected to be input and thought for the Library of Indonesian Institute of Arts Surakarta, namely how to promote library services through facebook in this modern era so that the academic community utilizes services library.

Keyword: facebook, library services, library promotion

Kata kunci: facebook, layanan perpustakaan, perpustakaan promosi

\begin{abstract}
ABSTRAK
Penelitian ini berjudul Pemanfaatan Media Sosial sebagai Sarana Promosi Layanan Perpustakaan Institut Seni Indonesia Surakarta. Tujuan penelitian untuk mengetahui media sosial (facebook) dapat memberikan kemudahan dalam mengenalkan berbagai layanan, memberikan informasi kepada pemustaka. Selain itu, untuk mengetahui facebook dapat digunakan untuk promosi informasi layanan dan kegiatan perpustakaan dengan efektif. Peneliti akan melihat laman facebook, mengumpulkan data dokumentasi pada laman facebook perpustakaan dan dianalisis menggunakan analisis deskriptif kualitatif. Penelitian menggunakan pendekatan kualitatif, penelitian yang menggambarkan mengenai fenomena, menggali data dengan wawancara kepada informan, observasi dan dokumentasi. Teknik peneliti dalam mencari data dilakukan melalui media online dengan wawancara terstruktur dan cecklist. Hanya saja jika diperlukan peneliti akan mememui langsung informan. Peneliti beranggapan bahwa facebook dapat dijadikan pengganti sarana promosi layanan perpustakaan dalam bentuk online atau softcopy dan secara serentak kepada banyak orang dan cepat bahkan terkadang langsung mendapat respon. Selain itu, promosi dengan media sosial dapat menarik minat pemustaka memanfaatkan fasilitas perpustakaan dan mengikuti kegiatan yang diselenggarakan perpustakaan serta sebagai media dokumentasi berbagai aktivitas di perpustakaan. Hasil penelitian ini diharapkan menjadi masukan bagi institusi, yakni bagaimana mempromosikan layanan perpustakaan melalui facebook di era modern ini sehingga civitas akademika memanfaatkan layanan perpustakaan.
\end{abstract}

(c) 2020 NJILS. All rights reserved. 


\section{A. PENDAhuluan}

Pada era modern ini akses internet begitu mudah, hampir pada semua tempat, rumah, atau instansi-instansi telah terhubung dengan jaringan internet. "Penetrasi internet di Indonesia pada Januari 2019 telah mencapai $56 \%$, artinya, $56 \%$ dari total penduduk di Indonesia telah terjangkau oleh internet. Data ini menunjukkan bahwa mayoritas penduduk merupakan pengguna internet dalam aktivitas kesehariannya" (Nistanto, 2019). Keberadaan internet telah mengubah perilaku masyarakat dalam melakukan pencarian informasi. Penggunaan perangkat teknologi seperti handphone, smartphone, laptop, dan jenis gadget lain menjadi satu hal yang melekat dalam keseharian sebagian masyarakat kita. Sebagian besar masyarakat menggunakan perangkat teknologi hampir dua pertiga waktu yang dimilikinya karena perangkat teknologi adalah bagian dari alat yang digunakan untuk bekerja. Selain untuk bekerja, masyarakat menggunakan perangkat teknologi untuk melakukan komunikasi atau pun untuk mengakses informasi.

Termasuk penggunaan media sosial (medsos) pun menjadi seperti makanan pokok seharihari masyarakat di sekitar kita, baik digunakan untuk berbagi informasi yang penting maupun sarana hiburan semata. Media sosial menjadi media online di dunia maya (internet), di mana, "Para penggunanya untuk melakukan interaksi sosial secara online. Di sana mereka bisa berkomunikasi, networking, berbagi, dan banyak kegiatan lainnya. Media daring yang sering digunakan saat ini adalah Instagram, Facebook, YouTube, Twitter, dan lain sebagainya" (Anjarwati, 2020).

Media merupakan sarana, penghubung, sedangkan sosial merupakan sesuatu yang berkenaan dengan masyarakat. Menurut Nasrullah (2015) media sosial adalah medium di internet yang memungkinkan pengguna merepresentasikan dirinya maupun berinteraksi, bekerja sama, berbagi, berkomunikasi dengan pengguna lain membentuk ikatan sosial secara virtual. Pendapat lainnya, media sosial adalah adalah alat komunikasi yang digunakan oleh pengguna dalam proses sosial (Mulawarman, 2017). Karakteristik media sosial yakni 1) pesan yang disampaikan tidak hanya untuk satu orang saja, namun bisa ke berbagai banyak orang, 2) pesan yang disampaikan bebas, tanpa melalui suatu gatekeeper, 3) pesan yang disampaikan cenderung lebih cepat dibanding media lainnya, 4) penerima pesanlah yang menentukan waktu interaksi (Gamble, 2015). Selanjutnya, terdapat skema klasifikasi dalam berbagai jenis media sosial.

"Proyek kolaborasi: website mengizinkan usernya untuk dapat mengubah, menambah, ataupun me-remove konten-konten yang ada di website ini contohnya Wikipedia. Blog dan 
microblog: user lebih bebas dalam mengekspresikan sesuatu di blog ini seperti curhat atau mengkritik kebijakan pemerintah contohnya twitter. Konten: para user dari pemustaka website ini saling meng-share konten-konten media baik seperti video, ebook, gambar, dan lain-lain. contohnya youtube. Situs jejaring sosial: aplikasi yang mengizinkan user untuk dapat terhubung dengan cara membuat informasi pribadi sehingga dapat terhubung dengan orang lain. Informasi pribadi itu bisa seperti foto-foto. contoh facebook, Virtual game world: dunia virtual, di mana dapat mengaplikasikan lingkungan 3D, di mana user bisa muncul dalam bentuk avatar-avatar yang diinginkan serta berinteraksi dengan orang lain selayaknya di dunia nyata. contohnya game online. Virtual social world: dunia virtual yang di mana pemustakanya merasa hidup di dunia virtual, sama seperti virtual game world, berinteraksi dengan yang lain. Namun, Virtual Social World lebih bebas, dan lebih ke arah kehidupan, contohnya second life" (Kaplan \& Haenlein, 2010).

Penggunaan media sosial di masyarakat dengan intensitas tinggi menjadi tantangan sekaligus peluang bagi perpustakaan dalam menjalankan fungsinya yang berorientasi kepada pengguna/pemustaka. Saat ini telah banyak perpustakaan yang menggunakan media sosial untuk mendukung layanannya. Keberadaan media sosial dimanfaatkan sebagai sarana promosi yang efektif. Media sosial seperti Youtube, Facebook, Tweeter dan Instagram dinilai mampu mengkomunikasikan informasi, layanan perpustakaan dengan lebih cair dan komunikatif. Tidak hanya itu, jangkauan media sosial yang seakan tidak terbatas dan bisa diakses kapan saja juga menjadi keunggulan tersendiri. Terlebih dengan semakin maraknya penggunaan telepon pintar, media sosial sudah menjadi bagian gaya hidup yang tak terpisahkan.

Perkembangan teknologi informasi seperti saat ini seharusnya dapat membawa perubahan lembaga penyedia informasi seperti perpustakaan. Jejaring sosial maupun media sosial dapat dimanfaatkan sebagai sarana pemustaka memperoleh informasi secara cepat, efektif dan efisien serta sebagai sarana promosi layanan perpustakaan. Promosi dan publikasi perpustakaan dimaksudkan agar semua program yang dimiliki dan kegiatan untuk pengguna perpustakaan (pemustaka) diketahui secara utuh dan jelas yang selanjutnya mendapat respon dan tanggapan oleh mereka.

Menurut Sherman (2013), promosi adalah seni dan teknik untuk berhubungan dengan masyarakat, memperkenalkan produk-produk yang dihasilkan serta pelayanan-pelayanan yang diberikan agar calon pemakai mengetahuinya. Sedangkan tujuan promosi perpustakaan adalah 1) 
memperkenalkan fungsi perpustakaan kepada masyarakat (pemustaka), 2) mendorong minat baca dan mendorong masyarakat agar menggunakan koleksi perpustakaan dengan maksimal dan menambah jumlah orang yang membaca, 3) memperkenalkan pelayanan dan jasa perpustakaan kepada masyarakat.

Kemudian, dalam metode memamerkan layanan perpustakaan dapat berupa nama dan logo, poster dan pamflet, pameran, media dan video, ceramah serta iklan. Sebagai sarana promosi perpustakaan dalam bentuk tercetak biasanya antara lain brosur, poster, map khusus perpustakaan, dan pembatas buku serta buku panduan perpustakaan. Dalam hal ini media sosial dapat dijadikan pengganti sarana promosi dalam bentuk online atau softcopy dan secara serentak kepada banyak orang dan cepat bahkan terkadang langsung mendapat respon atau tanggapan masyarakat. Selain itu, promosi dengan pemanfaatan media sosial dapat menarik minat pemustaka untuk memanfaatkan fasilitas perpustakaan dan mengikuti kegiatan-kegiatan yang diselenggarakan perpustakaan juga sebagai media dokumentasi berbagai aktivitas di perpustakaan.

Perpustakaan Institut Seni Indonesia (ISI) Surakarta juga telah memanfaatkan media sosial dalam menyampaikan informasi terkait layanan perpustakaan. Salah satu media sosial yang sering digunakan oleh Perpustakaan ISI Surkarta adalah facebook (FB). Namun, efektivitas media sosial ini belum banyak dimanfaatkan oleh perpustakaan. Sebenarnya perpustakaan menyadari bahwa sebagian besar penggunanya berada atau aktif di media sosial, terutama media sosial facebook dan WhaatApp (WA). Interaksi melalui media sosial antara pustakawan dan penggunanya juga dapat mencairkan suasana dan membangun image baru tentang pustakawan. Selain itu, pemanfaatan media sosial ini belum konsisten. Perpustakaan mempunyai akun facebook namun tidak secara rutin meng-update informasi tentang perpustakaan pada media sosial yang dimiliki. Bahkan, pesan yang masuk melalui media sosial terkadang terlambat direspons. Hal ini tentu saja membangun ketidakpercayaan pengguna terhadap akun media sosial facebook perpustakaan.

Facebook adalah website jejaring sosial dimana para pengguna dapat bergabung dengan komunitas seperti kota, pekerjaan, sekolah, daerah untuk melakukan interaksi dengan orang lain. Keistimewaan facebook terletak pada fasilitas yang variatif dan mudah dipelajari, seperti mencari teman dan memasukkannya dalam frienlist, dapat melakukan sharing audio, video, foto dan notes (Judhita, 2011). 
Namun, dengan berbagai kelebihan media sosial yang telah dibahas seperti tersebut di atas, perpustakaan juga harus memahami bagaimana metode pendekatan yang tepat agar tidak terkesan "terlalu banyak promosi". Jika tidak, para pembaca dari satu akun di jejaring sosial menjadi frustasi yang pada akhirnya akan berhenti untuk mengikuti segala perkembangan yang disajikan. Untuk itu, penelitian ini bertujuan untuk mengetahui media sosial (facebook) dapat memberikan kemudahan dalam mengenalkan berbagai layanan, memberikan informasi kepada pemustaka. Selain itu, untuk mengetahui facebook dapat digunakan untuk promosi informasi layanan dan kegiatan perpustakaan dengan efektif. Dalam penelitian ini penulis memberikan rumusan yang yakni pada; bagaimana pemanfaatan media sosial (facebook) sebagai sarana promosi layanan Perpustakaan ISI Surakarta.

\section{B. TINJAUAN PUSTAKA}

Penelitian tentang penggunaan media sosial di perpustakaan sudah pernah dilakukan dengan berbagai macam metode. Berikut ini penelitian-penelitian terdahulu yang membahas tentang pemanfaatan media sosial di perpustakaan:

Pertama, penelitian yang dilakukan oleh Istiana (2017), pustakawan dari Universitas Gadjah Mada Yogyakarta. Beliau telah menyelesaikan penelitian di lingkungan Perpustakaan Universitas Gadjah Mada Yogyakarta dengan judul Penggunaan Media Sosial oleh Perpustakaan. Teknik pengumpulan data menggunakan dokumentasi pada laman facebook perpustakaan yang diteliti. Hasil pengumpulan data dokumentasi pada laman facebook perpustakaan dianalisis menggunakan analisis deskriptif kuantitatif terhadap posting (kiriman) konten pada masing-masing facebook perpustakaan. Data dokumentasi pada facebook perpustakaan dibatasi pada tahun 2016. Kajian dari penelitian ini bertujuan untuk mengetahui frekuensi penggunaan facebook oleh perpustakaan dan bagaimana penggunaan facebook oleh perpustakaan.

Hasil kajian menunjukkan bahwa Perpustakaan UGM (ISIPOL) merupakan perpustakaan yang memiliki frekuensi penggunaan facebook paling sering, yakni setiap hari. Perpustakaan menggunakan facebook untuk mempromosikan koleksi perpustakaan, mempromosikan kegiatan atau layanan perpustakaan, mengunggah foto kegiatan yang telah dilakukan perpustakaan, mengembangkan jasa layanan sirkulasi, menginformasikan kegiatan internal perpustakaan, 
mempromosikan kegiatan dari perpustakaan lain, menginformasikan berbagai hal yang penting bagi pengguna, dan menyapa penggunanya. Setiap perpustakaan dalam penggunaan facebook menunjukkan aktivitas dan intensitas yang berbeda-beda.

Kedua, Penelitian Damayanti (2014) tentang pemanfaatan twitter sebagai media information sharing di perpustakaan. Penelitian ini dilakukan pada Perpustakaan Wilayah Kota Surabaya. Dari penelitian tersebut Damayanti menyatakan, "Twitter memiliki potensi yang besar sebagai media sharing antara perpustakaan dengan penggunanya, karena selalu terhubung dengan internet dan jangkauannya bisa diperluas dengan retweet" (Damayanti, 2014).

Ketiga, Assegaff (2017) dari STIKOM Dinamika Bangsa melakukan penelitian dengan judul Evaluasi Pemanfaatan Media Sosial sebagai Sarana Knowledge Sharing. Penelitian ini merupakan evaluasi pemanfaatan aplikasi media sosial yang digunakan sebagai sarana berbagi pengetahuan oleh dosen di Indonesia dalam sebuah grup virtual di facebook.

"Model Kesuksesaan Sistem Informasi oleh Delone dan McLean digunakan sebagai teori dasar dengan mempertimbangkan faktor karaterisktik individu. Sebuah model penelitian dan 12 (dua belas) buah hipotesis dikembangkan dalam penelitian ini. Model dan hipotesis kemudian diuji dan divalidasi menggunakan data yang diperoleh dari sebuah survey yang dilaksanakan secara online. Survey secara online dilakukan pada sebuah grup dosen di Indonesia. Sebanyak 160 kuesioner diisi oleh anggota komunitas online tersebut dan dinyatakan valid dan digunakan untuk analisis lebih lanjut. Data yang diperoleh kemudian dianalisis menggunakan Partial Least Square (PLS) memanfaatkan perangkat lunak Smart PLS V2. Pengujian meliputi 'measurement model' dan 'structural model'”, (Assegaff, 2017).

Hasil dari pengolahan data mengindikasikan bahwa pemanfaatan media sosial (facebook) telah berhasil menjadi sarana bagi para akademisi di Indonesia dalam berbagi informasi dan pengetahuan. Temuan penelitian ini yakni bahwa, "Faktor "system use" dan "user satisfaction" adalah faktor utama yang mempengaruhi "individual impact", sementara itu faktor lain seperti karateristik individu mempengaruhi system quality dan information quality. Sedangkan information quality mempengaruhi system use, dan system use mempengaruhi user satisfaction" (Assegaff, 2017).

Dari semua penelitian tersebut di atas terdapat persamaan maupun perbedaan. Persamaanya yakni sama-sama meneliti tentang pemafaatan media sosial, sedangkan perbedaannya, adalah 1) media sosial yang dijadikan subjek penelitian yakni ada yang facebook, 
ada juga yang twitter; 2) metode penelitian yang digunakan dan; 3) penelitian dilakukan pada tempat dan waktu yang berbeda.

\section{METODE PENELITIAN}

Dalam penelitian ini peneliti menggunakan pendekatan kualitatif, bahwa penelitian kualitatif sering disebut metode penelitian naturalistik karena penelitiannya dilakukan pada kondisi yang alamiah (natural setting). (Sugiyono, 2013). Permasalahan dalam penelitian kualitatif masih bersifat sementara, tentative dan akan berkembang atau berganti setelah peneliti berada di lapangan (Sugiyono, 2013). Penulis menggunakan jenis penelitian deskriptif kualitatif. Informan penelitian yakni tiga pustakawan di ISI Surakarta. Teknik penentuan informan yang digunakan dalam penelitian ini adalah bersifat purposive (bertujuan), yaitu pemilihan informan berdasarkan pada kriteria tertentu yang ditentukan oleh peneliti agar didapati informan (narasumber) yang cocok untuk penelitian.

Analisis data yang digunakan adalah model analisis interaktif. Analisis interaktif merupakan proses penelitian yang berlangsung secara terus menerus sampai tuntas (Sugiyono, 2013). Dalam keperluan analisis data tersebut, teknik pengumpulan data yang dilakukan peneliti dengan observasi, study literatur, dokumentasi dan wawancara. Selanjutnya aktifitas dalam menganalisa data yakni; pengumpulan data, reduksi data, dan penyajian data, serta penarikan kesimpulan atau verifikasi. Keabsahan data menggunakan trianggulasi, triangulasi teknik ini untuk menguji kredibilitas data dilakukan dengan cara mengecek data kepada sumber yang sama dengan teknik yang berbeda. Misalnya data diperoleh dengan wawancara, kemudian dicek dengan observasi, dokumentasi, atau kuesioner. Jika dengan teknik pengujian kredibilitas data tersebut, menghasilkan data yang berbeda-beda, maka peneliti melakukan diskusi lebih lanjut kepada sumber data yang bersangkutan atau yang lain, untuk memastikan data mana yang dianggap benar.

\section{HASIL DAN PEMBAHASAN}

Perpustakaan Institut Seni Indonesia (ISI) Surakarta telah memanfaatkan facebook dalam menyampaikan informasi layanan perpustakaan dan kegiatan yang akan maupun sudah diselenggarakan. Facebook ini sangat mudah digunakan oleh pustakawan di ISI Surakarta, 
kesulitan dalam pengoperasian, membuat status, menciptakan informasi, merespon tanggapan dan sebagainya hampir tidak ada kendala. Hasil observasi pada facebook, menunjukkan bahwa kompetensi manajemen informasi, pustakawan mampu mencari informasi dari facebook, mengidentifikasi kebutuhan informasi pengguna. Pustakawan mampu menelusuri informasi dari berbagai sumber, menentukan keyword dari sebuah informasi dan mampu menciptakan informasi melalui facebook. Selain itu, yang terpenting bagi pustakawan di ISI Surakarta yakni mampu menyampaikan informasi kepada pengguna dan mampu mengevaluasi informasi yang diperoleh dari pengguna facebook.

Sedangkan kompetensi interpersonal pustakawan yakni mampu berkomunikasi dengan baik dengan sesama pengguna facebook dan mendengarkan pendapat orang lain. Pustakawan mampu merespon dan memberikan umpan balik kepada pengguna facebook. Facebook dapat memberikan kemudahan dalam mengenalkan berbagai layanan, memberikan informasi kepada pemustaka dengan gaya kekinian atau gaya yang diminati mahasiswa saat ini.

Selanjutnya, dapat dinyatakan bahwa media sosial mampu memberikan kemudahan sebagai sarana informasi. Setelah adanya internet segala informasi dapat disampaikan secara daring, baik melalui web perpustakaan atau melalui media sosial. Desiminasi informasi melalui media sosial atau internet ini efektif tersampaikan karena sebagian pemustaka berada di internet artinya pengguna berada di dunia maya. Facebook dapat memberikan kemudahan bagi pustakawan dalam menyampaikan informasi, baik kepada sesama pustakawan seprofesi maupun kepada pemustaka. Informasi dengan cepat dapat kita peroleh. Disamping itu, dapat terjalin kerjasama layanan dan komunikasi ilmiah dan membentuk jaringan baru sesama pustakawan perguruan tinggi di Indonesia

Informan menyatakan bahwa pustakawan menggunakan facebook karena menarik dan mudah pengoperasiannya. Informasi yang disampaikan berbentuk softcopy atau online dan menjangkau dunia maya tanpa batas. Informasi yang disampaikan beragam, dapat berupa hiburan, berita, pengumuman, informasi penting, dokumentasi kegiatan dan info perpustakaan tentunya. 


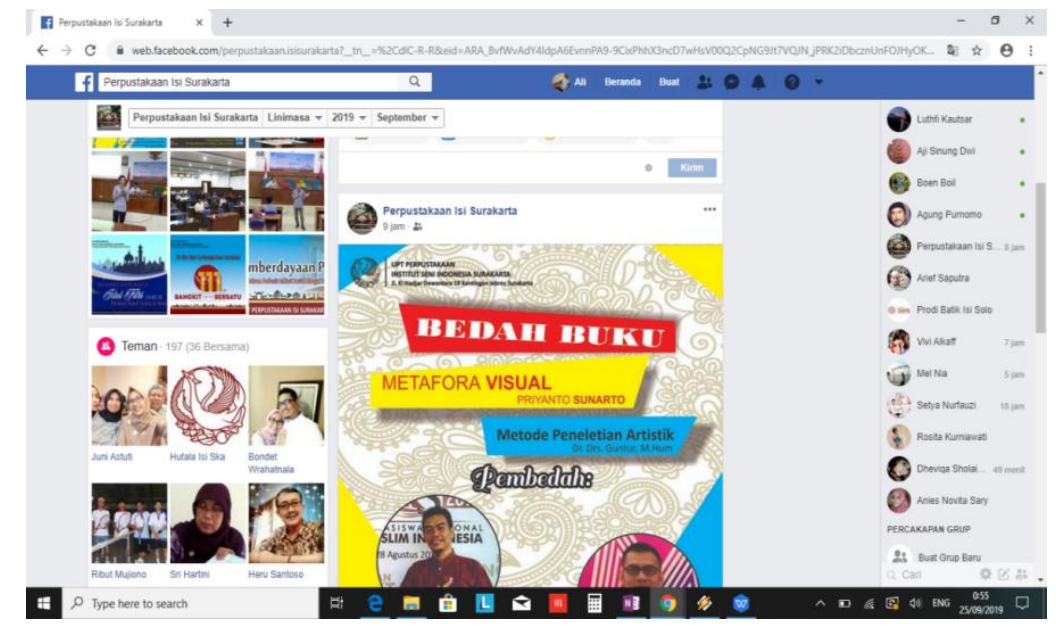

Gambar 1 Tampilan facebook share kegiatan bedah buku yang telah dilaksanakan tanggal 26 September 2019 di Perpustakaan ISI Surakarta

Sumber: https://web.facebook.com/photo.php

Promosi dan publikasi perpustakaan merupakan cara pustakawan menyampaikan semua program yang dimiliki ataupun kegiatan untuk pengguna perpustakaan agar diketahui secara utuh dan jelas yang selanjutnya mendapat respon dan tanggapan oleh mereka. Perpustakaan dalam memamerkan layanan perpustakaan dapat berupa nama dan logo, poster dan pamflet, pameran, media dan video, ceramah serta iklan. Sebagai sarana promosi perpustakaan dalam bentuk tercetak biasanya antara lain brosur, poster, map khusus perpustakaan, dan pembatas buku serta buku panduan perpustakaan. Pada tanggal 2 Januari tahun 2019 secara resmi UPT Perpustakaan ISI Surakarta membuat portal resmi di media sosial salah satunya media facebook. Apa yang membedakan media promosi tercetak dengan media promosi online salah satunya adalah respon, bagi pembaca respon dapat secara langsung atau tertunda. Kemudian dapat langsung dijawab oleh admin. Informan penelitian menyatakan bahwa media sosial sebagai promosi layanan perpustakaan efektif.

Pertama, Informasi dapat secara cepat dan serentak dalam jumlah banyak tersebar ke pengguna facebook. Promosi bisa melalui berbagai media, lewat sosialisasi kepada mahasiswa baru, namun itu hanya sekali di awal masuk kuliah. Hal ini kurang efektif, karena waktunya sedikit dan mahasiswa terkadang sudah lelah. Kedua, informan menyatakan promosi dengan menggunakan tulisan melalui facebook efektif, namun akan lebih efektif berupa foto atau berupa video. Foto dan video bagi pemustaka lebih menarik daripada sekedar kata-kata atau berupa tulisan saja. Ketiga, penggunaan media sosial (facebook) digunakan oleh perpustakaan untuk 
berbagai keperluan, bahwa penggunaan media sosial, antara lain: 1) untuk menginformasikan koleksi baru perpustakaan; 2) memperkenalkan fungsi perpustakaan kepada masyarakat (pemustaka); 3) mendorong minat baca dan mendorong masyarakat agar menggunakan koleksi perpustakaan dengan maksimal dan menambah jumlah orang yang membaca, misalnya dengan cara menyampaikan poster hari buku dunia; 4) memperkenalkan pelayanan dan jasa perpustakaan kepada masyarakat.

Penggunaan facebook dapat juga berupa interaksi antara pustakawan dan penggunanya, interaksi ini dapat mencairkan suasana dan membangun image baru tentang pustakawan. Namun harus dilakukan dengan konsisten. Masih cukup banyak perpustakaan yang mempunyai akun facebook namun tidak secara rutin meng-update informasi tentang perpustakaan pada media sosial yang dimiliki. Bahkan, pesan yang masuk melalui media sosial terkadang terlambat direspons. Hal ini tentu saja membangun ketidakpercayaan pengguna terhadap akun media sosial perpustakaan

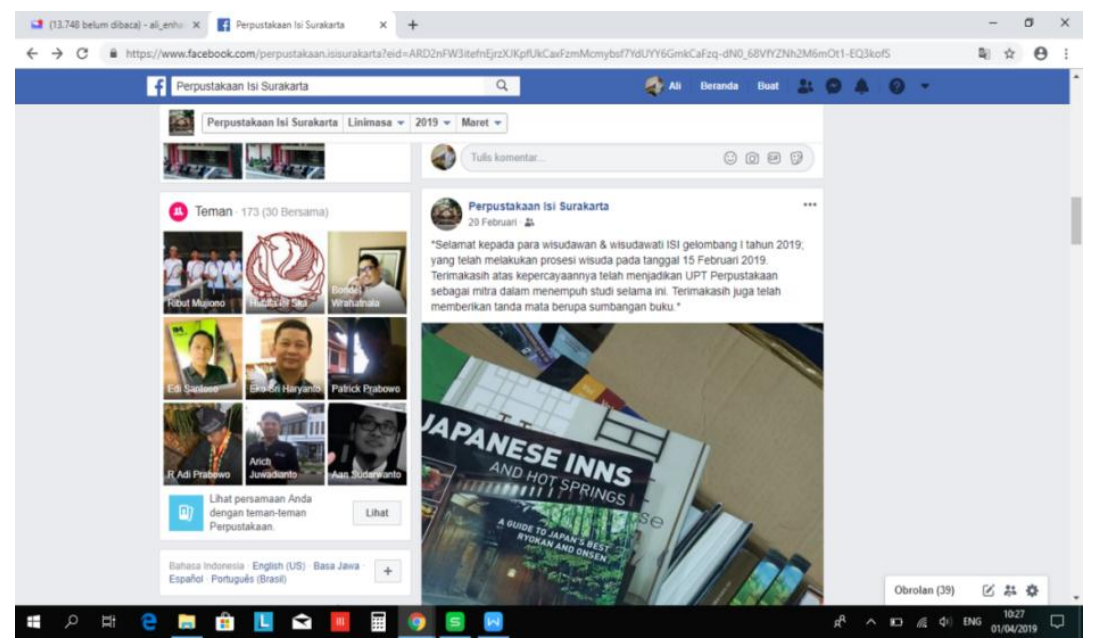

Gambar 2 Laman facebook Perpustakaan ISI Surakarta menyampaikan adanya sumbangan buku dari mahasiswa alumni (wisuda Februari 2019) sekaligus ucapan terima kasih kepada para alumni ISI Surakarta.

Sumber: https://web.facebook.com/photo.php

\section{E. KESIMPULAN DAN SARAN}

Hasil penelitian menunjukkan media sosial facebook dapat memberikan kemudahan sebagai sarana informasi dan dapat dijadikan sebagai promosi layanan perpustakaan yakni sebagai berikut, media sosial facebook memberikan kemudahan sebagai sarana informasi karena 
mudah pengoperasiannya, informasi yang disampaikan berbentuk softcopy atau online dapat menjangkau dunia maya tanpa batas. Informasi yang disampaikan beragam, dapat berupa hiburan, berita, pengumuman, informasi penting, dokumentasi kegiatan dan info perpustakaan. Respon secara langsung dari pemustaka dapat diperoleh, sebaliknya admin juga dapat segera menjawabnya. Informan juga menyatakan bahwa media sosial sebagai promosi layanan perpustakaan. Pertama, Informasi dapat secara cepat dan serentak dalam jumlah banyak tersebar ke pengguna facebook. Kedua, promosi dengan menggunakan tulisan melalui facebook sudah baik, namun akan lebih baik lagi jika menampilkan foto atau berupa video.

Dari hasil penelitian ini penulis menyampaikan saran, Perpustakaan ISI Surakarta diharapkan menggunakan media sosial facebook secara intensif sebagai media promosi layanan yang dimiliki dan kegiatan-kegiatan perpustakaan. Namun, informasi yang disampaikan sebaiknya dilengkapi video dan foto, karena hal ini akan lebih baik bahkan sering kali langsung mendapatkan respon dari pemustaka. Pustakawan diharapkan sering menciptakan informasi yang berkaitan dengan perpustakaan dan disampaikan melalui facebook Perpustakaan ISI Surakarta. Sebagian besar pustakawan membuat status hanya jika ada kegiatan saja atau menunggu adanya kegiatan. Selanjutnya pustakawan juga perlu memperhatikan adanya respon dari pengguna perpustakaan. Perpustakaan yang mempunyai akun facebook namun tidak secara rutin mengupdate informasi tentang perpustakaan dan terlambat bahkan tidak merespon pesan yang masuk melalui facebook akan membangun ketidakpercayaan pengguna terhadap akun facebook perpustakaan tersebut.

\section{DAFTAR PUSTAKA}

Anjarwati, J. (2020). Media sosial: Pengertian, jenis, fungsi, dan contoh. FA Tekno. https://tekno.foresteract.com/media-sosial/

Arikunto, Suharsimi. 2010. Prosedur Penelitian Suatu Pendekatan Praktek. Jakarta: Rineka Cipta.

Assegaff, S. (2017). Evaluasi pemanfaatan media sosial sebagai sarana knowledge sharing. Jurnal Manajemen Teknologi, 16(3), 271-293. https://journal.sbm.itb.ac.id/index.php/mantek/rt/printerFriendly/2114/0

Gamble, Michael and Teri Kwal Gamble. 2015. Communication Work 8 th edition, New York: McGraw-Hill.

Istiana, Purwani. Penggunaan Media Sosial oleh Perpustakaan, Jurnal Libraria , Vol. 5, No. 1, Juni 2017. http://journal.stainkudus.ac.id/index.php/Libraria/article/view/2252/0. diakses pada 2 Oktober 2019.

Judhita, Chistiany, 2011, "Hubungan Penggunaan Situs Jejaring Sosial facebook Terhadap Perilaku Remaja di Kota Makasar” dalam Jurnal Penelitian IPTEK_KOM , Vol. 13, No. 1 Tahun 2011. 
Kaplan, A. M. \& Haenlein, M. (2010). "Users of the world, united The challenges and opportunities of Social Media". Business Horizons 53(1): 59-68.

Martoatmodjo, Kharmidi. 2014. Manajemen Perpustakaan Khusus, Jakarta: Universitas Terbuka.

Moleong, 2014. Metodologi Penelitian Kualitatif, Edisi Revisi. Bandung: PT. Remaja Rosdakarya.

Mulawarman, Nurfitri, Aldila Dyas. Perilaku Pengguna Media Sosial beserta Implikasinya Ditinjau dari Perspektif Psikologi Sosial Terapan. Buletin Psikologi (Print) 2017, Vol. 25, No. 1, 36 - 44 ISSN 0854-7106

Nasrullah, Rulli. 2015. Media Sosial; Persfektif Komunikasi, Budaya, dan Sosioteknologi. Bandung: Simbiosa Rekatama Media.

Nistanto, R. K. (2019). Riset: Penetrasi internet Indonesia naik jadi 56 persen. Kompas.Com, 7. https://tekno.kompas.com/read/2019/02/04/11420097/riset-penetrasi-internet-indonesia-naik-jadi-56persen?page $=$ all

Sugiyono, 2013. Metode Penelitian Kuantitatif, Kualitatif dan Kombinasi (Mixed Methods), Edisi Baru, Bandung: Alfabeta 
